\title{
Relationship of Histopathology Grading with Molecular Subtypes of Breast Cancer Patients in Haji Adam Malik General Hospital 2016-2018
}

\author{
Muhammad Furqan ${ }^{1}$, Pimpin Utama Pohan ${ }^{1}$ \\ ${ }^{1}$ Department of Oncology Surgery, Faculty of Medicine, Universitas Sumatera Utara, Medan
}

\begin{abstract}
Background: Breast cancer symptoms are often not felt clearly by patients, as a result many patients who come in an advanced stage. This will affect the prognosis and cure rate of the patient. There are several factors that influence the prognosis of breast cancer, including histopathological grade, and classic immunohistochemical markers such as estrogen receptors, progesterone receptors, and HER2. In addition, breast cancer can be 4 main molecular subtypes, namely Luminal A, Luminal B, HER2-Overexpression, and Triple Negative / Basal-Like. Objectives: This study aims to determine the relationship between histopathological grade with the molecular subtypes of breast cancer patients in Haji Adam Malik General Hospital in 2016-2018. Methods: This is analytical cross-sectional research using a consecutive-sampling technique. Data were obtained secondary from the medical records of breast cancer patients at Haji Adam Malik General Hospital in 2016-2018 and then analyzed with the chi-square test. From 1005 cases of breast cancer during the 2016-2018 period, 131 samples were taken in this study. Results: Of the 131 samples, the highest histopathological grade was grade 2 with 53 people $(40.5 \%)$, followed by 41 people $(31.3 \%$ ) with grade 3 , and 37 people (28.2\%) with grade 1 . The most molecular subtypes were Luminal A with 38 people (29\%), followed by 33 people (25.2\%) with Luminal B, 31 people (23.7\%) with HER-2 Overexpression, and 29 people $(22.1 \%)$ with Triple Negative / Basal-like. From the analysis of the chisquare test obtained $\mathrm{p}$ value of 0.045 . Conclusion: There is a relationship between histopathological grade with molecular subtypes of breast cancer patients.
\end{abstract}

Keywords: breast cancer, histopathological grade, immunohistochemistry, molecular subtypes

\section{ABSTRAK}

Latar Belakang: Gejala-gejala kanker payudara sering tidak dirasakan dengan jelas oleh pasien, akibatnya banyak pasien yang datang dalam keadaan stadium lanjut. Hal ini akan mempengaruhi prognosis dan tingkat kesembuhan pasien. Terdapat beberapa faktor yang mempengaruhi prognosis dari kanker payudara, antara lain grading histopatologi, dan marker imunohistokimia klasik seperti reseptor estrogen, reseptor progesteron, dan HER2. Selain itu, kanker payudara dapat diklasifikasikan menjadi 4 subtipe molekuler utama, yaitu Luminal A, Luminal B, HER2-Overexpression, dan Triple Negative/Basal-Like. Tujuan: Penelitian ini bertujuan untuk mengetahui hubungan antara grading histopatologi dengan subtipe molekuler pasien kanker payudara di RSUP Haji Adam Malik Tahun 2016-2018. Metode: Penelitian ini merupakan penelitian analitik menggunakan desain cross-sectional dengan teknik pengambilan sampel consecutive-sampling. Data diperoleh secara sekunder dari rekam medis pasien kanker payudara di RSUP Haji Adam Malik pada tahun 2016-2018 dan kemudian dianalisis dengan uji chi-square. Dari 1005 kasus kanker payudara selama periode 2016-2018, diambil sampel pada penelitian ini sebanyak 131 buah rekam medis. Hasil: Dari 131 sampel, grading histopatologi terbanyak terdapat pada grade 2 dengan 53 orang (40,5\%), diikuti 41 orang (31,3\%) dengan grade 3 , dan 37 orang $(28,2 \%)$ dengan grade 1. Subtipe molekuler terbanyak yaitu Luminal A dengan 38 orang (29\%), diikuti 33 orang $(25,2 \%)$ dengan Luminal B, 31 orang (23,7\%) dengan HER-2 Overexpression, dan 29 orang $(22,1 \%)$ dengan Triple Negative/Basal-like. Dari hasil uji chi-square diperoleh nilai p sebesar 0,045. Kesimpulan: Terdapat hubungan antara grading histopatologi dengan subtipe molekuler pasien kanker payudara.

Kata kunci: grading histopatologi, imunohistokimia, kanker payudara, subtipe molekuler Received [30 Dec 2019] | Revised [29 May 2020] | Accepted [1 Jun 2020]

\section{INTRODUCTION}

Cancer is a condition that occurs when abnormal cells grow in a way that is not controlled and can damage the surrounding tissue or spread to other parts of the body. ${ }^{[1]}$ One type of cancer that is frightening for all women in the world is breast cancer. ${ }^{[2]}$ 
Breast cancer is a type of cancer with the highest incidence along with lung cancer in 2.09 million cases followed by colorectal cancer (1.8 million), prostate (1.28 million), skin (1.04 million), and stomach (1.03 million). Breast cancer is the most common type of cancer among women in the world with a mortality rate reaching 627,000 women in $2018 .{ }^{[3]}$ In Indonesia, the incidence of breast cancer in 2019 reached 42.1 per 100,000 population with an average death rate of 17 per 100.000 population. ${ }^{[4]}$ Meanwhile, North Sumatra ranks seventh in Indonesia with an incidence rate of 0.4 per 100,000 population. ${ }^{[5]}$

Breast cancer symptoms are often not felt clearly by the patient and, as a result, many patients seek treatment when the disease is already in an advanced stage (stage III and IV). This is according to data from Dharmais Cancer Hospital medical records in 2010 showed that around $85 \%$ of breast cancer patients were already at an advanced stage when they came to the hospital. This will affect the prognosis and cure rate of the patient. ${ }^{[6,7]}$ Factors that influence the prognosis of breast cancer are divided into two groups, major and minor prognostic factors. Major prognostic factors include: invasive or in situ cancer, lymph node metastases, distant metastases, tumor size, advanced local disease, and inflammatory cancer. While minor prognostic factors consist of: histologic subtypes, tumor grading, proliferation rate, DNA content and classical immunohistochemical (IHC) markers such as estrogen receptors (ER), progesterone receptors (PR), and human epidermal growth factor receptor-2 (HER2). ${ }^{[8,9]}$

Tumor histology grading is a tumor based on tumor cell abnormalities and tumor tissue seen under a microscope. This grading is determined based on the assessment of tubule/gland formation, nucleus pleomorphism and the number of mitoses. Determination of tumor histology grading using the Patey \& Sarff, Blood \& Richardson method modified by Elston \&
Ellis. Grading is associated with a life expectancy of 10 years, namely grade I $(85 \%)$, grade II $(60 \%)$, and grade III $(45 \%)$. Grade I shows the best prognosis, grade II shows a moderate prognosis, while grade III shows the worst prognosis. ${ }^{[10,11]}$

Breast cancer has different histopathological features and biological characteristics so that it shows a different treatment response and different therapeutic strategies must be given as well. ${ }^{[12,13]}$ Therefore, breast cancer grouping into molecular subtypes is carried out to determine the type of treatment that is more accurate. ${ }^{[8]}$ According to the St. Gallen consensus in 2011, breast cancer can be classified into 4 main molecular subtypes based on the molecular expression of estrogen receptors (ER), progesterone receptors (PR), human epidermal receptor 2 (HER2), and proliferative index (Ki-67), namely Luminal A (ER +, PR +, HER2-, and $\mathrm{Ki}-67 \leq 14 \%)$, Luminal $\mathrm{B}(\mathrm{ER}+, \mathrm{PR}+$, HER2-, and Ki-67> 14\%; ER + and/or PR +, HER 2 +), HER 2 + Type (ER-, PR-, and HER 2 +), and Triple Negative / Basal-Like (ER-, PR-, and HER2). ${ }^{[14,15]}$

Based on research conducted by Kadivar et al. in 2012, there was a relationship between molecular subtypes and tumor characteristics, such as size, grading, and lymphovascular infiltration. Luminal $\mathrm{A}$ is the most frequent molecular subtype, next luminal B, then basal-like and finally, type HER2. Basal-like types and HER2 generally have grade III, whereas luminal $\mathrm{A}$ has grade $\mathrm{I}^{[16]}$ According to Shomaf et al. in 2013, in HER2 and basallike types, the majority of cases were grade III tumors, and none of the cases were grade I tumors. ${ }^{[17]}$

According to research at RSUP Dr. M. Djamil Padang, molecular subtypes of Triple-Negative were more common in grade III which was $52.6 \%$, HER 2 occurred more in grade I which was $33.3 \%$, Luminal $\mathrm{B}$ was more common in grade II which was $36.6 \%$ and Luminal A was more common in grade I, $33.3 \%$. This proves that histopathological grading will affect the 
occurrence of molecular subtypes in breast cancer patients. $^{[18]}$

Research on the relationship of histopathological grading with molecular subtypes of breast cancer patients has not been done much in Indonesia. Based on the description above, researchers are interested in researching with the title Relationship of Histopathology Grading with Molecular Subtypes of Breast Cancer Patients in Haji Adam Malik General Hospital Medan in 2016-2018.

\section{METHODS}

This type of research is observational analytic with a cross-sectional design to look for the relationship between independent variables (histopathological grading) with the dependent variable (molecular subtype) in breast cancer patients. This research was conducted at the Haji Adam Malik General Hospital in July 2019 to October 2019. The population in this study were all breast cancer patients listed in the medical record data at the Haji Adam Malik General Hospital in Medan in 2016-2018. The sample in this study was taken with a non-probability sampling technique of consecutive sampling type where samples that met the selection criteria were included in the study until the required number of samples was met. From 1005 cases of breast cancer in the period 2016-2018, 131 samples that met the inclusion and exclusion criteria were taken in this study.

Inclusion criteria in this study were patients diagnosed with breast cancer in 2016-2018, there were grading diagnoses on histopathological examination, and there were diagnoses of molecular subtypes on immunohistochemical examination.

Data is processed through several stages, namely Editing, Coding, Entring, Cleaning, and Saving. The data obtained were then presented descriptively in narrative form, proportion distribution tables, and statistical analysis to look for the relationship of histopathological grading with molecular subtypes in breast cancer patients with the Chi-square test in the statistical application program.

\section{RESULTS}

Table 1. Frequency distribution of samples by

\begin{tabular}{lll} 
Age group & $\begin{array}{l}\text { Amount } \\
(\mathbf{n})\end{array}$ & $\begin{array}{l}\text { Percentage } \\
(\boldsymbol{\%})\end{array}$ \\
\hline$\leq 25$ years & 2 & 1.5 \\
26-35 years & 10 & 7.6 \\
36-45 years & 61 & 46.6 \\
46-55 years & 31 & 23.7 \\
56-65 years & 22 & 16.8 \\
$>$ 66 years & 5 & 3.8 \\
\hline Total & 131 & 100 \\
\hline
\end{tabular}

Based on table 1, it is known that from 131 cases of breast cancer in the Haji Adam Malik General Hospital in 2016-2018, the majority were in the 36-45 years age group of 61 people $(46.6 \%)$, then followed by the $46-55$ year age group as many as 31 people $(23.7 \%)$, the age group of 56-65 years were 22 people (16.8\%), the age group of 26-35 years were 10 people (7.6\%), the age group $>66$ years were 5 people $(3.8 \%)$, and the age group $\leq 25$ years were 2 people $(1.5 \%)$. The mean age (mean) in this study was 46.61 years $($ median $=44$ years, $\mathrm{SD}=$ 9.902).

Table 2. Distribution of histopathological grading

\begin{tabular}{lll}
\hline $\begin{array}{l}\text { Grading } \\
\text { Histopathology }\end{array}$ & $\begin{array}{l}\text { Amount } \\
(\mathbf{n})\end{array}$ & $\begin{array}{l}\text { Percentage } \\
(\mathbf{\%})\end{array}$ \\
\hline Grade 1 & 37 & 28.2 \\
Grade 2 & 53 & 40.5 \\
Grade 3 & 41 & 31.3 \\
\hline Total & 131 & 100 \\
\hline
\end{tabular}

Based on table 2, it can be seen that from 131 cases of breast cancer in Haji Adam Malik General Hospital 2016-2018, the highest grade of histopathology grading was grade 2 with 53 people (40.5\%), followed by grade 3 with 41 people (31, $3 \%$ ), and grade 1 as many as 37 people $(28.2 \%)$. 
Table 3. Frequency distribution of molecular subtypes

\begin{tabular}{lll}
\hline $\begin{array}{l}\text { Molecular } \\
\text { Subtype }\end{array}$ & $\begin{array}{l}\text { Amount } \\
(\mathbf{n})\end{array}$ & $\begin{array}{l}\text { Percentage } \\
(\%)\end{array}$ \\
\hline Luminal A & 38 & 29 \\
Luminal B & 33 & 25.2 \\
HER-2 & 31 & 23.7 \\
Overexpression & & \\
TNBC/Basal-like & 29 & 22.1 \\
\hline Total & 131 & 100 \\
\hline
\end{tabular}

Based on table 3, it can be seen that from 131 cases of breast cancer in Haji Adam Malik General Hospital in 20162018, the highest molecular subtypes were Luminal A with 38 people (29\%), then the second was 33 Luminal B subtypes (25 people), $2 \%$ ), the third was the HER-2 Overexpression subtype of 31 people
(23.7\%), and TNBC / Basal-like was the molecular subtype with the smallest occurrence rate of 29 people $(22.1 \%)$.

Table 4 shows that based on histopathological grading, Luminal B molecular subtypes were more often found in grade 1 in 15 cases $(11.5 \%$ ), while grade 2 was often found in Luminal A molecular subtypes in 16 cases (12.2\%), HER -2 as many as 15 cases $(11.5 \%)$, and TNBC as many as 14 cases $(10.7 \%)$. The results in Table 4 are then performed a chi-square test with a significance level of $0.05(\alpha=5 \%)$, the $\mathrm{p}$ value obtained is $0.045(\mathrm{p}<0.05)$ which means there is a relationship between histopathological grading with molecular subtypes of breast cancer patients.

Table 4. Relationship of histopathological grading with molecular subtypes

\section{Molecular Subtypes}

\begin{tabular}{|c|c|c|c|c|c|c|c|c|c|c|c|c|}
\hline & \multirow{2}{*}{\multicolumn{3}{|c|}{ Luminal A }} & \multirow{2}{*}{\multicolumn{2}{|c|}{ Luminal B }} & \multirow{2}{*}{\multicolumn{2}{|c|}{ HER-2 }} & \multirow{2}{*}{\multicolumn{4}{|c|}{ Total }} & \multirow{3}{*}{ p value } \\
\hline & & & & & & & & & & & & \\
\hline & & $\mathbf{N}$ & $\%$ & $\mathbf{N}$ & $\%$ & $\mathbf{N}$ & $\%$ & $\mathbf{N}$ & $\%$ & $\mathbf{N}$ & $\%$ & \\
\hline \multirow{3}{*}{ Grade } & 1 & 13 & 9.9 & 15 & 11.5 & 6 & 4.6 & 3 & 2.3 & 37 & 28.2 & \multirow{3}{*}{0.045} \\
\hline & 2 & 16 & 12.2 & 8 & 6.1 & 15 & 11.5 & 14 & 10.7 & 53 & 40.5 & \\
\hline & 3 & 9 & 6.9 & 10 & 7.6 & 10 & 7.6 & 12 & 9.2 & 41 & 31.3 & \\
\hline Total & & 38 & 29 & 33 & 25.2 & 31 & 23.7 & 29 & 22.1 & 131 & 100 & \\
\hline
\end{tabular}

\section{DISCUSSION}

From the results of this study, the majority of breast cancer patients were in the age group $36-45$ years $(46.6 \%)$ and at least in the age group $\leq 25$ years $(1.5 \%)$. The results of this study can be said in accordance with research conducted by Siadati et al. in 2015 which found that breast cancer patients were most prevalent in the age group of 35-45 years, as well as research conducted by Geethamala et al. in 2015 which found that the majority of patients breast cancer is at the 3rd and 4th decade $(76 \%) .{ }^{[19,20]}$ In addition, this study's data are consistent with research from the American Cancer Society in 2017 which states that this disease rarely occurs in women younger than 25 years. ${ }^{[21]}$ Age is a significant risk factor for breast cancer. ${ }^{[22]}$ Currently, the incidence of breast cancer is more common in young adult women with an age range of $<40$ years. ${ }^{[23]}$ This can be due to an increase in the world population itself, increased awareness of both patients and doctors in diagnosing diseases, increased case reporting, as well as the role of other risk factors such as internal factors namely parity at a young age, family history of breast cancer or other malignancies, mutation of the Breast Cancer Susceptibility Gene 1 (BRCA 1) or Breast Cancer Susceptibility Gene 2 (BRCA 2), p53 mutations, and environmental factors such as radiation therapy due to Hodgkin's disease, exposure to external hormones, use 
of hormone replacement therapy, and lifestyle (smoking, alcohol consumption, rarely exercising). ${ }^{[24]}$

In this study, most samples had grade 2 $(40.5 \%)$ from the results of the histopathological examination on medical records. The results of this study are consistent with the 2016 study of Firdaus et al. in RSUP M. Djamil Padang who found that the majority of breast cancer sufferers had histopathological grading at grade 2 of $62.1 \%$, followed by grade 3 at $26.8 \%$, and grade 1 at $9.1 \% .^{[18]}$ This is also supported by the results of 2016 Syukri et al's study which also found grade 2 was the most common histopathological grading of $53.8 \%$, followed by grade 3 of $44 \%$ and grade 1 of $1.8 \%$. $^{[25]}$ Tumor grading is a tumor based on the abnormality of tumor cells and tumor tissue seen under a microscope. Grading is determined based on how different tumor cells look from normal breast cells, and how fast they grow. Grading is assessed using a scoring system for 3 tumor characteristics (tubule/gland formation, nucleus pleomorphism, number of mitoses) and will reflect the aggressiveness of tumor cells ie. the higher the grade, the more aggressive the tumor. Grading is the main prognostic factor that must be reported in the results of histopathological examination of breast cancer. Grading is associated with a life expectancy of 10 years, namely grade 1 $(85 \%)$, grade $2(60 \%)$, and grade $3(45 \%)$. Grade 1 shows the best prognosis, grade 2 shows a moderate prognosis, while grade 3 shows the worst prognosis. ${ }^{[10,11,26]}$

From the results of the study, it was found that the majority of the samples had Luminal A molecular subtypes (29\%). The results of this study are in line with the study of Su et al. in 2011 in China which found that the most frequent molecular subtypes were Luminal A at $48.6 \%$, followed by Luminal B at $16.7 \%$, HER-2 Overexpression at $13.7 \%$, and TNBCBasal-like $12.9 \% .{ }^{[27]}$ Luminal A is the most abundant molecular subtype in this study. This result is supported by several studies outside and in Indonesia which stated the same thing. ${ }^{[16,28-30]}$ In contrast, the results of the 2012 El-Fatemi et al. study in North Africa found that the Luminal B subtype was more dominant than the other subtypes with a percentage of $41.8 \% .{ }^{[31]}$ Meanwhile, different results were obtained in the 2012 Ly et al. study in Mali which found that the TNBC / Basal-like subtype was the most frequent molecular subtype with a percentage of $51.5 \%{ }^{[32]}$ Ethnics and genes of breast cancer sufferers play a role in differences in the number of cases of each of these molecular subtypes. In Asia, the type A luminal is more common than other types, whereas in Africa the type B luminal and TNBC / Basal-like type are more often found, this type has a worse prognosis than luminal A. In addition, different proportions of subtypes in the population is associated with several risk factors for breast cancer such as age, BMI, menopause status, family history, parity and duration of breastfeeding, ${ }^{[31,33]}$ while this study only looked at histopathological grading and the patient's lymph node status. The most common Luminal A molecular subtypes found in this study may be due to several risk factors such as high BMI, not breastfeeding, and early menarche. ${ }^{[29]}$ In addition, the study of Devi et al. in 2012 also mentioned that influence of multi factors (westernization) namely sedentary lifestyle and obesity can increase the incidence of Luminal A molecular subtypes. $^{[33]}$

Based on the results of this study, it was found that the Luminal B molecular subtypes were more often found in grade 1, while the Luminal A, HER-2, and TNBC molecular subtypes were more often found in grade 2. Chi-square test results obtained $\mathrm{p}$ value $=0.045$ which means there is a relationship between histopathological grading with molecular subtypes in breast cancer patients. These results are consistent with the study of Salhia et al. in 2011 in Egypt and Kadivar et al. in 2012 in Iran which stated that there was a relationship between histopathological grading and 
molecular subtypes of breast cancer patients with $\mathrm{p}=0.044(\mathrm{p}<0.05)$ and $\mathrm{p}$ $<0.001(\mathrm{p}<0.05){ }^{[16,34]}$ The study of Salhia et al. also found the same thing with this study that the molecular subtypes of Luminal A, HER-2, and TNBC were most commonly found in grade 2 with successive percentages. namely $78.5 \%, 86.7 \%$, and 92.3\%. ${ }^{[34]}$ However, the molecular subtype Luminal B is more commonly found in grade 2 so there are differences with this study. Meanwhile, in the study of Kadivar et al, it was found that the TNBC molecular subtype was mostly found in grade 3 with a percentage of $63.5 \%$. The other subtypes, namely Luminal A, Luminal B, and HER-2 are mostly found in grade 2 with percentages of $56.7 \%, 69.7 \%$, and $54 \%$ respectively. ${ }^{[16]}$ Several studies in Indonesia have concluded the hypothesis test that is consistent with this study although there are differences in the proportion of molecular subtypes based on histopathological grading. This can be seen in the 2016 study of Firdaus et al. in RSUP Dr. M. Djamil Padang who stated that there was a relationship between histopathological grading and molecular subtypes of breast cancer patients with a value of $p=0.032(p<0.05)$. In that study, it was found that TNBC molecular subtypes were more common in grade 3, 52.6\%, HER2 occurred more in grade 1, 33.3\%, Luminal B occurred more in grade 2, $36.6 \%$, and Luminal A more common in grade 1 , which is $33.3 \% .^{[18]}$ Meanwhile, a study by Setyawati et al. in 2018 in Yogyakarta also stated that there was a significant relationship between histopathological grading with molecular subtypes of breast cancer with a value of $p$ $=0.013(\mathrm{p}<0.05)$ with them finding that the Luminal A molecular subtype had the highest frequency in grade 1 namely $17.6 \%$, Luminal B, HER2, and TNBC were more common in grade 3 , namely $79.4 \%, 70.8 \%$ and $77.8 \%$ respectively. ${ }^{[29]}$

In several studies, it was found that the Luminal A molecular subtype is associated with grade 1 which has a good prognosis and tends to grow slowly. ${ }^{[16,19,20,28,35-38]}$ This is because the Luminal A subtype has a high expression of several gene markers for well-differentiated tumors such as FOX A1, GATA3, and Bcl-2. In contrast, the Luminal A subtype has a low EGFR marker expression. EGFR marker expression indicates a breast tumor has a poor prognosis. Meanwhile, ER and PR expression in this subtype is an indicator that a tumor can respond to hormone therapy so that it has a better prognosis. ${ }^{[39]}$

In this study Luminal B molecular subtypes were most commonly found in grade 1, this is different from some studies that found that Luminal B molecular subtypes had the most high-grade tumors (grade 3). These results are related to several characteristics of the Luminal B subtype, namely the larger tumor size, extensive node involvement, and advanced tumor stage when compared to the Luminal A subtype. ${ }^{[40]}$ Another theory says that negative expression of $\mathrm{Bcl}-2$ and positive expression of HER-2 in the Luminal B subtype is associated with poor prognosis and low survival rates. ${ }^{[39]}$

Breast cancer with the HER-2 subtype has a large percentage of tumors with a diameter and tends to grow more aggressively. ${ }^{[37]}$ In this study, the most HER-2 molecular subtypes were found in grade 2 . These results are different from several studies that found that the most HER-2 molecular subtypes occur at high grading (grade 3 ). This result is associated with a significant relationship between HER-2 / neu expression with high histological grading. HER-2 / neu is an epidermal growth factor on the cell surface that transmits growth signals to the cell nucleus. Excessive expression of HER-2 from its receptors is associated with a poor prognosis. $^{[19]}$ In addition, this poor prognosis can occur due to differences in molecular characteristics with the Luminal subtype. The HER-2 subtype has higher levels of c-Met, survivin, and EGFR expression, while PTEN and Bcl-2 
expressions are lower when compared to the Luminal subtype. ${ }^{[39]}$

Although in this study TNBC subtypes were mostly found in grade 2 (10.2\%), TNBC subtypes had the highest grade 3 percentage $(9.2 \%)$ when compared to other subtypes. This is in accordance with several studies which found that the TNBC subtype had a relatively high percentage in grade 3 , so it had a poor prognosis such as the HER2 subtype. This is associated with a high incidence of p-53 mutations, downregulation of retinoblastoma $(\mathrm{Rb})$ and increased levels of expression of $\mathrm{p}-16$, Glut-1 and CAIX. ${ }^{[36]}$

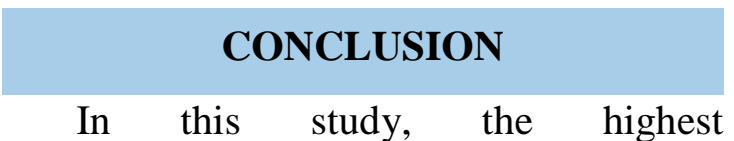
histopathological grading was grade 2, followed by grade 3 and grade 1, while the most molecular subtypes were Luminal A subtypes, followed by Luminal B, HER-2 Overexpression, and TNBC / Basal-like.

Based on histopathological grading, Luminal B molecular subtypes were found mostly in grade 1, whereas molecular subtypes Luminal A, HER-2, and TNBC were most commonly found in grade 2 .

Based on the results of the chi-square test, it can be concluded that there is a relationship between histopathological grading and molecular subtypes of breast cancer patients in Haji Adam Malik General Hospital in 2016-2018.

\section{RECOMMENDATIONS}

If other researchers will conduct research in the same field, it is advisable to conduct more in-depth research on the relationship of the results of other histopathological examinations such as lymphatic and vascular metastases to the molecular subtypes of breast cancer. In addition, to improve accuracy in determining the HER-2 Overexpression subtype, researchers suggest conducting insitu hybridization tests to confirm immunohistochemical examination with HER-2 2+ scores.

\section{REFERENCES}

[1] Refshauge A. Cancer in Australia an Overview 2012. 74th ed. Australian Institute of Health and Welfare. 2012;1-5

[2] InfoDatin Bulan Peduli Kanker Payudara 2016. Jakarta: Kementerian Kesehatan RI Pusat Data dan Informasi. 2016. p. 11.

[3] World Health Organization. Cancer [Internet]. Geneva: World Health Organization; 2018 [cited 2019 Apr 13]. Available from: https://www.who.int/newsroom/fact-sheets/detail/cancer

[4] Kementerian Kesehatan Republik Indonesia. Hari Kanker Sedunia 2019 [Internet]. Jakarta: Kementerian Kesehatan Republik Indonesia; 2019 Jan 31 [cited 2019 Apr 13]. Available from:

http://www.kemkes.go.id/article/vie w/19020100003/hari-kankersedunia-2019.html

[5] Riset Kesehatan Dasar 2013. Badan Penelitian dan Pengembangan Kesehatan Kementerian Kesehatan RI; 2013.

[6] Dwidayati N. Analisis cure rate penderita kanker payudara. J Sains dan Teknol. 2012;10(2):141-52.

[7] Nasdaldy. Jakarta: Dharmais Hospital National Cancer Center; 2011 [cited 2019 Apr 13]. Available from: www.dharmais.co.id

[8] Dai X, Li T, Bai Z, Yang Y, Liu X, Zhan J, et al. Breast cancer intrinsic subtype classification, clinical use and future trends. 2015;5(10):292943.

[9] Kumar V, Abbas AK, Aster JC, editors. Robbins basic pathology. 10th ed. Philadelphia: Elsevier; 2017. p. 739-47.

[10] Kementerian Kesehatan Republik Indonesia. Pedoman Nasional 
Pelayanan Kedokteran Tatalaksana Kanker Payudara. 2018;1-111.

[11] Stevens A, Lowe J, Scott I. Core Pathology. 3rd ed. United Kingdom: Elsevier; 2009. p. 445-7

[12] Opdahl S, Hagen AI, Romundstad PR, Akslen LA, Haugen OA, Vatten $\mathrm{LJ}$, et al. Molecular subtypes, histopathological grade and survival in a historic cohort of breast cancer patients. 2013;140(3):463-73. doi: 10.1007/s10549-013-2647-2

[13] Rakha EA, Reis-filho JS, Baehner F, Dabbs DJ, Decker T, Eusebi V, et al. Breast cancer prognostic classifi cation in the molecular era: the role of histological grade. Breast Cancer Res. 2010;12(207):12. doi: $10.1186 / \mathrm{bcr} 2607$

[14] Goldhirsch A, Wood WC, Coates AS, Gelber RD, Thu B. Strategies for subtypes - dealing with the diversity of breast cancer : highlights of the St Gallen International Expert Consensus on the primary therapy of early breast cancer 2011. Ann Oncol. 2011;22:1736-47. doi: 10.1093/annonc/mdr304

[15] Lv M, Li B, Mao X, Yao F, Jin F. Predictive role of molecular subtypes in response to neoadjuvant chemotherapy in breast cancer patients in Northeast China. Asian Pacific J Cancer Prev. 2011;12:24117.

[16] Kadivar M, Mafi N, Joulaee A, Shamshiri A. Breast cancer molecular subtypes and associations with clinicopathological characteristics in iranian women, 2002 - 2011. Asian Pacific J Cancer Prev. 2012;13(5):1881-6. doi: $\underline{\text { 10.7314/apjcp.2012.13.5.1881 }}$

[17] Shomaf M, Masad J, Najjar S, Faydi D. Distribution of breast cancer subtypes among Jordanian women and correlation with histopathological grade: molecular subclassification study. J R Soc Med
Short Reports. 2013;4(10):1-6. doi: 10.1177/2042533313490516

[18] Firdaus VR, Asri A, Khambri D, Harahap WA. Hubungan grading histopatologi dan infiltrasi limfovaskular dengan subtipe molekuler pada kanker payudara invasif di Bagian Bedah RSUP. Dr. M. Djamil Padang. J Kesehat Andalas. 2016;5(1):165-72. doi: 10.25077/jka.v5i1.463

[19] Siadati S, Sharbatdaran M, Nikbakhsh N, Ghaemian N. Correlation of ER, PR and HER2/Neu with other prognostic factors in infiltrating ductal carcinoma of breast. Iran J Pathol. 2015;10(3):2216.

[20] Geethamala K, Murthy SV, Vani BR, Rao S. Histopathological grade versus hormone receptor status in breast carcinoma- treasure the past. Ijbr. 2015;6(7):466-71. doi: 10.7439/ijbr.v6i7.2203

[21] American Cancer Society. Breast cancer risk and prevention [Internet]. Atlanta: American Cancer Society; 2017 [cited 2019 Apr 7]. Available from: http://www.cancer.org

[22] Katz J. Breast cancer risk factors [Internet]; 2018 [cited 2018 Nov 22]. Available from: https://emedicine.medscape.com/arti cle/1945957-overview

[23] Gabriel CA, Domchek SM. Breast cancer in young women. Breast Cancer Res. 2010;12(212):1-10. doi: 10.1186/bcr2647

[24] Hartaningsih NM, Sudarsa IW. Kanker payudara pada wanita usia muda di Bagian Bedah Onkologi Rumah Sakit Umum Pusat Sanglah Denpasar tahun 2002 - 2012. EJournal Medika Udayana. 2014;3(6):1-14.

[25] Syukri NA, Fidiawati WA, Tripriadi ES. Profil pemeriksaan indeks proliferatif Ki-67 pada penderita kanker payudara di RSUD Arifin 
Achmad. JOM FK Universitas Riau. 2016;3(1):1-13.

[26] ESMO. What is breast cancer? Let us answer some of your questions. Eur Soc Med Oncol. 2018;1-55.

[27] Su Y, Zheng Y, Zheng W, Gu K, Chen Z, Li G, et al. Distinct distribution and prognostic significance of molecular subtypes of breast cancer in Chinese women: a population-based cohort study. BMC Cancer. 2011;11(1):292. doi: 10.1186/1471-2407-11-292

[28] Elesawy BH, Abd El Hafez A, Shawky AE, Arafa M. Immunohistochemistry-based subtyping of breast carcinoma in Egyptian women: a clinicopathologic study on 125 patients. Ann Diagn Pathol. 2014;18(1):21-6. doi: 10.1016/j.anndiagpath.2013.10.005

[29] Setyawati Y, Rahmawati Y, Widodo I, Ghozali A, Purnomosari D. The association between molecular subtypes of breast cancer with histological grade and lymph node metastases in Indonesian woman. Asian Pacific J Cancer Prev. 2018;19(5):1263-8. doi: 10.22034/APJCP.2018.19.5.1263

[30] Widodo I, Dwianingsih EK, Triningsih E, Utoro $\mathrm{T}$. Clinicopathological features of Indonesian breast cancers with different molecular subtypes. 2014;15(15):6109-13. doi: 10.7314/apjcp.2014.15.15.6109

[31] El Fatemi H, Chahbouni S, Jayi S, Moumna K, Melhouf MA, Bannani $\mathrm{A}$, et al. Luminal B tumors are the most frequent molecular subtype in breast cancer of North african women: an immunohistochemical profile study from Morocco. Diagn Pathol. 2012;7(1):1-7. doi: 10.1186/1746-1596-7-170

[32] Ly M, Antoine M, Dembl AK, Levy P, Rodenas A, Tour BA, et al. High incidence of triple-negative tumors in Sub-saharan Africa: a prospective study of breast cancer characteristics and risk factors in Malian women seen in a Bamako University Hospital. Oncol. 2012;83(5):257-63. doi: $10.1159 / 000341541$

[33] Devi CR, Tang TS, Corbex M. Incidence and risk factors for breast cancer subtypes in three distinct South-East Asian ethnic groups: Chinese, Malay and natives of Sarawak, Malaysia. Int J Cancer. 2012;131(12):2869-77. doi: $10.1002 / \mathrm{ijc} .27527$

[34] Salhia B, Tapia C, Ishak EA, Gaber $\mathrm{S}$, Berghuis B, Hussain $\mathrm{KH}$, et al. Molecular subtype analysis determines the association of advanced breast cancer in Egypt with favorable biology. BMC Womens Health. 2011;11(44):1-9. doi: 10.1186/1472-6874-11-44

[35] Ambroise M, Ghosh M, Mallikarjuna V, Kurian A. Immunohistochemical profile of breast cancer patients at a tertiary care hospital in North India. Asian Pacific J Cancer Prev. 2011;12(3):625-9.

[36] Choi J, Jung WH, Koo JS. Metabolism-related proteins are differentially expressed according to the molecular subtype of invasive breast cancer defined by surrogate immunohistochemistry.

Pathobiology. 2012;80(1):41-52. doi: $10.1159 / 000339513$

[37] Errahhali ME, Errahhali ME, Ouarzane M, El Harroudi T, Afqir S, Bellaoui M. First report on molecular breast cancer subtypes and their clinico-pathological characteristics in Eastern Morocco: series of 2260 cases. BMC Womens Health. 2017;17(1):1-11. doi: 10.1186/s12905-016-0361-z

[38] Onitilo AA, Engel JM, Greenlee RT, Mukesh BN. Breast cancer subtypes based on ER/PR and Her2 expression: comparison of clinicopathologic features and 
survival. Clin Med Res. 2009;7(12):4-13. doi: $\underline{10.3121 / \mathrm{cmr} .2009 .825}$

[39] Tamaki M, Kamio T, Kameoka S, Kojimahara N, Nishikawa T. The relevance of the intrinsic subtype to the clinicopathological features and biomarkers in Japanese breast cancer patients. World J Surg Oncol. 2013;11:1-13. doi: 10.1186/14777819-11-293

[40] Hashmi AA, Aijaz S, Khan SM, Mahboob R, Irfan M, Zafar NI, et al. Prognostic parameters of luminal A and luminal B intrinsic breast cancer subtypes of Pakistani patients. World J Surg Oncol. 2018;16(1):1-6. doi: $\underline{10.1186 / \mathrm{s} 12957-017-1299-9}$ 